\title{
Yield of soybean, pasture and wood in integrated crop-livestock-forest system in Northwestern Paraná state, Brazil ${ }^{1}$
}

\author{
Rendimento de soja, forragem e madeira em sistema integração lavoura-pecuária- \\ floresta no Noroeste do Paraná
}

\author{
Julio Cezar Franchini ${ }^{2}$, Alvadi Antonio Balbinot Junior ${ }^{2 *}$, Fernando Ribeiro Sichieri ${ }^{3}$, Henrique Debiasi ${ }^{2}$ e \\ Osmar Conte ${ }^{2}$
}

\begin{abstract}
The integrated crop- livestock-forest system can enhance the production of soybeans, meat and wood in regions characterized by sandy soils and warm climate. The aim of this study was to evaluate the yield of soybean, Urochloa ruziziensis grass and eucalyptus in an integrated system during the first four years after the establishment of eucalyptus in the northwestern region of Paraná state, Brazil. The experiment was established in October 2009, using soybean (summer) - U. ruziziensis (autumn/winter) succession between single rows of Corymbia maculata (eucalyptus species). The spacing between tree rows and eucalyptus plants in the row were 14 and $4.2 \mathrm{~m}$, respectively. Adjacent plots had the same soybean- $U$. ruziziensis succession, but without eucalyptus. The spatial variability of soybean grain yields and grass shoot dry matter production was evaluated with and without trees, and the data was analyzed using geostatistics, with the results expressed as spatial variability maps. The tree component did not significantly affect soybean yield in the first two growing seasons. In the 3rd and 4th growing season (2011/12 and 2012/13), the interference of eucalyptus reduced the soybean grain yield by 2.9 and $27.0 \%$, respectively, and the effect was stronger close to the tree rows. In July 2012, the tree component reduced the shoot dry matter productivity of U. ruziziensis by $29.2 \%$. At 19 and 35 months after eucalyptus planting, the cumulative wood volume production was 0.73 and $5.17 \mathrm{~m}^{3} \mathrm{ha}^{-1}$, respectively.
\end{abstract}

Key words: Eucalyptus. Glycine max L.. Urochloa ruziziensis. Sandy soil. Spatial and temporal variability.

\begin{abstract}
RESUMO - O sistema integração lavoura-pecuária-floresta pode viabilizar a produção de soja, carne e madeira em regiões que apresentam solos arenosos e clima quente. O objetivo desse trabalho foi avaliar a produtividade de soja, Urochloa ruziziensis e eucalipto em sistema integrado, durante os quatro primeiros anos de implantação, na região Noroeste do Paraná. O experimento foi implantado em outubro de 2009, usando a sucessão soja-U. ruziziensis nos entre renques simples de Corymbia maculata (espécie de eucalipto utilizada). Os espaçamentos entre renques e plantas foram de 14 e 4,2 m, respectivamente. Em área contígua, foi usada a mesma sucessão de culturas, mas sem o eucalipto. Os rendimentos de soja e de capim foram avaliados na ausência e presença de árvores, de forma espacializada, sendo os dados analisados por geoestatística e os resultados expressos por mapas de variabilidade espacial. O componente arbóreo não afetou a produtividade de soja nas duas primeiras safras. Na terceira e quarta safras, 2011/12 e 2012/13, a redução de produtividade ocasionada pela interferência do eucalipto foi de 2,9 e $27,0 \%$, sendo mais intensa nas proximidades das árvores. Em julho de 2012, constatou-se que o componente arbóreo reduziu em 29,2\% a produtividade de massa seca do capim. Aos 19 e 35 meses após a implantação, a produção acumulada de madeira foi de 0,73 e $5,17 \mathrm{~m}^{3} \mathrm{ha}^{-1}$.
\end{abstract}

Palavras-chave: Eucalipto. Glycine max L.. Urochloa ruziziensis. Solo arenoso. Variabilidade espacial e temporal.

\footnotetext{
* Autor para correspondência

${ }^{1}$ Recebido para publicação para em 20/01/2014; aprovado em 10/06/2014

Pesquisa financiada pela Empresa Brasileira de Pesquisa Agropecuária/EMBRAPA

${ }^{2}$ Embrapa Soja, rodovia Carlos João Strass, s/n, Warta, Londrina-PR, Brasil, 86.001-970, julio.franchini@embrapa.br, alvadi.balbinot@ embrapa.br, henrique.debiasi@embrapa.br,osmar.conte@embrapa.br

${ }^{3}$ Fartura Consultoria, fernandosichieri@bol.com.br
} 


\section{INTRODUCTION}

Agriculture has faced great challenges such as the production of food in high quality and quantity, energy, fiber, wood and other products with a minimum negative impact on the environment, as well as the mitigation of gases causing the greenhouse effect (FOLEY et al., 2005; NAIR et al., 2010). In this context, the most appropriate alternative is the use of production systems that efficiently utilize the resources available in the agro-system, with a view to improve the quality of soil, water and air, reduce the consumption of inputs and the generate higher income per area (BALBINOT JR et al., 2011; CARVALHO et al., 2010). A production system that can be used to achieve this goal is the integrated crop-livestockforest system (CLFS), especially in environments with limitations for crop and animal production as isolated activities (NAIR, 2011; REGANOLD et al., 2011).

The CLFS can be an important strategy for increasing the sustainability of agriculture in the Northwest of Paraná. This region occupies a total area of 3.2 million hectares, representing approximately $16 \%$ of the total area of the state (SÁ; CAVIGLIONE, 1999). Medium and sandy-textured soils originated from Caiuá sandstone, with high susceptibility to erosion and low water storage capacity, are predominant in this region (FIDALSKI et al., 2013). The sand contents reach $850-900 \mathrm{~g} \mathrm{~kg}^{-1}$, and the contents of phosphorus, potassium, calcium, magnesium and organic matter are generally critical for crop growth (COSTA et al., 2012). The climate is humid subtropical (Cfa, according to the Köppen's classification), with high temperatures, especially in the summer. Therefore, considering the soil and climate characteristics, the grain production in this region is highly susceptible to losses resulting from abiotic stresses, especially drought.

The tree component in CLFS can provide environmental and economic benefits, such as soil and water conservation, carbon sequestration, wood production, and improved animal welfare, which can increases milk and beef production. However, it is necessary to evaluate the tree component effects on annual crops and forage species that compose the system, since all the components of the CLFS compete for environmental resources (water, light and nutrients) (ROZADOS-LORENZO et al., 2007). Thus, the study of spatial and temporal variability of grain yields and forage production can be a useful tool to assess the arboreal component effects on these crops (PACIULLO et al., 2011). These effects are likely associated with the proximity to tree rows as well as the age of the trees. In this context, geostatistical analysis has been used to study the spatial variability of productivity of pastures and grain species (LIMA et al., 2009; MIGUEL et al., 2009; SILVA et al., 2008).

The hypothesis of this research is that the yield of soybean and grass are affected by tree component, and the magnitude of this effect is spatial and timedependent. Therefore, this study aimed to evaluate the yield of soybean grains, $U$. ruziziensis dry matter, and eucalyptus wood in a CLFS during the first four years after the establishment of eucalyptus, in the northwestern region of Paraná State, Brazil.

\section{MATERIAL AND METHODS}

The experiment was established in October 2009 in an area of 10 ha, located in the municipality of Santo Inacio, northwest region of Paraná State, Brazil (latitude 22 45'56" S, longitude 51 ${ }^{\circ} 50$ '30" W and altitude $386 \mathrm{~m}$ ). The soil was classified as Typic Haplustox according to USDA Soil Classification System. Some soil physical and chemical properties determined before the establishment of the experiment are presented in Table 1. Prior to the establishment of the trees, the area was cultivated with perennial pasture, Urochloa brizantha cv. Marandu. The CLFS started with the cultivation of soybean and eucalyptus species Corymbia maculata Hill \& Johnson (Eucalyptus maculata Hook), planted in single rows spaced $14 \mathrm{~m}$, with a spacing of $4.2 \mathrm{~m}$ between trees in a row, resulting in a density of 170 trees $\mathrm{ha}^{-1}$. The eucalyptus seedlings were obtained from seeds. For the eucalyptus planting, a reference row was marked in level, and then the other rows were placed keeping a uniform distance of $14 \mathrm{~m}$ between rows to ensure soil and water conservation and facilitate the mechanized operations. Prior to the eucalyptus planting, a subsoiler was used to prepare the soil only in the planting rows. After the eucalyptus planting, the fertilizer (NPK 08-24-18) was applied at a rate of $0.25 \mathrm{~kg}$ per plant, at $10 \mathrm{~cm}$ depth and $25 \mathrm{~cm}$ alongside the tree. The weed control in the tree rows was carried out manually in the first year, and with application of glyphosate in the 2 nd year.

In 2009/10, 2010/11, 2011/12 and 2012/13 growing seasons, the soybean was sown in the experimental area in November using a row spacing of $50 \mathrm{~cm}$, and 250,000 plants $\mathrm{ha}^{-1}$. The cultivars used were FTS Campo Mourão RR (2009/10 and 2010/11), and BMX Potência RR (2011/12 and 2012/13). In all growing seasons, the soybean was fertilized with $20 \mathrm{~kg} \mathrm{ha}^{-1}$ of nitrogen, $80 \mathrm{~kg}$ $\mathrm{ha}^{-1}$ of phosphorus, and $80 \mathrm{~kg} \mathrm{ha}^{-1}$ of potassium, applied $0.05 \mathrm{~m}$ below and alongside the seeds simultaneously with the sowing. Soybean seeds were inoculated with Bradyrhizobium elkanii and B. japonicum every growing 
Tabela 1 - Some soil physical and chemical properties of the experimental site, Santo Inácio, PR

\begin{tabular}{lccccccccccc}
\hline Soil layers & $\mathrm{pH}^{1}$ & $\mathrm{~K}$ & $\mathrm{Ca}$ & $\mathrm{Mg}$ & $\mathrm{CTC}^{2}$ & $\mathrm{~V}^{3}$ & $\mathrm{P}^{4}$ & $\mathrm{OC}^{4}$ & Clay & Silt & Sand \\
\hline$(\mathrm{cm})$ & \multicolumn{7}{c}{$\mathrm{cmol}_{\mathrm{c}} \mathrm{dm}^{-3}$} \\
$0-25$ & 4.7 & 0.07 & 1.25 & 0.34 & 5.43 & 30.3 & 10.0 & 10.6 & 101 & 18 & 881 \\
$25-50$ & 4.6 & 0.05 & 1.03 & 0.30 & 4.72 & 29.3 & 1.8 & 5.3 & 150 & 15 & 835 \\
\hline
\end{tabular}

${ }^{1}$ Soil $\mathrm{pH}\left(0.01 \mathrm{~mol} \mathrm{~L}^{-1}\right.$ of $\left.\mathrm{CaCl}_{2}\right) .{ }^{2} \mathrm{CEC}$ : cation exchange capacity at $\mathrm{pH} 7.0 .{ }^{3} \mathrm{~V}=$ base saturation. ${ }^{4} \mathrm{P}=$ phosphorus available by Mehlich-1 solution. ${ }^{5} \mathrm{C}=$ organic carbon by Walkley-Black method

season. Weed control was achieved using glyphosate at a dosage of $720 \mathrm{~g}$ a.e. ha ${ }^{-1}$. Other management practices including crop management, and control of pests and diseases strictly followed the technical recommendations for soybean production in the region. The soybean was harvested in March of each growing season. From March to October 2013, the experimental area was cultivated with Urochloa ruziziensis, sown with row spacing of 20 $\mathrm{cm}$ and without fertilizer application.

In 2009/10 and 2010/11 growing seasons, soybean yield was assessed in 20 samples of $3 \mathrm{~m}^{2}$ collected within and outside tree rows. In 2011/12 and 2012/13, from a total of 26 soybean rows cultivated between two eucalyptus rows, samples composed by two soybean rows of $3 \mathrm{~m}$ long were collected in the rows 2 and $3 ; 7$ and $8 ; 13$ and 14; 19 and 20; 24 and 25. The sampling was repeated 17 times at intervals of 10 meters in each pair of soybean rows, totaling 85 samples along a total distance of $160 \mathrm{~m}$. Additionally, an area measuring 160 $\mathrm{m}$ long $\mathrm{x} 11.25 \mathrm{~m}$ wide (26 soybean rows) was delimited outside the eucalyptus rows, and samples composed by two soybean rows were taken in the rows 2 and 3; 7 and $8 ; 13$ and 14; 19 and 20; 24 and 25. Similarly to the procedure adopted in the area between the eucalyptus rows, the sampling was repeated 17 times at intervals of 10 meters in each pair of soybean rows, totaling 85 samples. After sampling, soybean plants were threshed, cleaned and the grains weight. The soybean grain yield was corrected to a moisture content of $130 \mathrm{~g} \mathrm{~kg}^{-1}$. The soybean yields were mapped for each growing season, and comparing the areas located outside with those between the eucalyptus rows, it was possible to infer the spatial and temporal variability in soybean yields resulting from the presence of eucalyptus.

In July 2012, 30 days after the removal of the cattle from de pasture, the shoot dry mass yield of the grass were evaluated. Samples were collected from an area of $0.5 \mathrm{~m}^{2}$ at seven equidistant positions between two eucalyptus rows (transversally to the direction of the eucalyptus rows) and eight segments, $8 \mathrm{~m}$ apart each other in the direction of the tree rows, resulting in a distance of 56 meters and a total of 56 samples. This procedure was repeated in an adjacent area with similar soil conditions, but without eucalyptus interference. Then, the grass samples were dried in a forced-air oven at $65{ }^{\circ} \mathrm{C}$ to constant weight to determine the shoot dry mass yield.

The soybean yields and shoot dry mass yield of the grass were subjected to geostatistical analysis (VIEIRA et al., 2002). In order to determine the spatial dependence of the variables, autocorrelation was obtained by fitting semivariogram functions using Spherical, Gaussian and Exponential models. Kriging was done to interpolate the data, enabling the spatial mapping according to the model that resulted in the best fit as shown in Table 2 .

In order to enable comparisons among different growing seasons, the soybean grain yields and the shoot dry mass production of the grass were normalized to the respective maximum value obtained without the presence of eucalyptus, according to the formula: $\mathrm{Y}_{\mathrm{N}}=\left(\mathrm{Y}_{\mathrm{P}} / \mathrm{Y}_{\mathrm{M}}\right) * 100$, where: $\mathrm{Y}_{\mathrm{N}}=$ normalized soybean yield or normalized shoot dry mass yield of the grass; $Y_{P}=$ Soybean or shoot dry mass yield $\left(\mathrm{kg} \mathrm{ha}^{-1}\right)$ at a given point between two eucalyptus rows ; and $\mathrm{Y}_{\mathrm{M}}=$ Maximum soybean or shoot dry mass yield without the tree component.

At 19 and 35 months after the eucalyptus planting, the tree density was evaluated and the following variables were measured in $20 \%$ of the tress: tree height, using a steel telescopic ruler; the trunk diameter at breast height (DBH), by means of a tape-measure; average volume of wood per tree, estimated by the equation: tree volume $\left(\mathrm{m}^{3}\right)=0.7854 * \mathrm{DBH}^{2} *$ height $* 0.33$; and the wood volume per hectare estimated by multiplying the tree volume by the tree density.

\section{RESULTS AND DISCUSSION}

The soil of the experimental area is characterized by very low clay and high sand contents (Table 2). Due to the low physical protection of organic matter exerted by clays and the warm climate of the region (FRANCHINI et al., 2011), the organic carbon contents are low, especially in the $25-50 \mathrm{~cm}$ layer, resulting in low CEC and natural 
Table 2 - Parameters of the semivariogram models fitted to the soybean grain yield and shoot dry mass production of Urochloa ruziziensis, within and outside the eucalyptus rows during the 2011/12 and 2012/13 growing seasons, at Santo Inácio, PR

\begin{tabular}{|c|c|c|c|c|c|}
\hline & \multirow[b]{2}{*}{ Model $^{\mathrm{a}}$} & \multicolumn{3}{|c|}{ Parameters $^{\mathrm{b}}$} & \multirow[b]{2}{*}{$\mathrm{R}^{2}$} \\
\hline & & $\mathrm{C}_{0}$ & $\mathrm{C}_{1}$ & $\mathrm{a}$ & \\
\hline & \multicolumn{5}{|c|}{ 2011/12 (soybean) } \\
\hline Within & EXP & 6.54 & 11.92 & 38.47 & 0.87 \\
\hline \multirow[t]{2}{*}{ Outside } & EXP & 5.32 & 4.58 & 6.73 & 0.44 \\
\hline & \multicolumn{5}{|c|}{ 2012/13 (soybean) } \\
\hline Within & GAU & 46.97 & 15.36 & 6.57 & 0.68 \\
\hline \multirow[t]{2}{*}{ Outside } & SPH & 23.83 & 16.88 & 21.84 & 0.52 \\
\hline & \multicolumn{5}{|c|}{2012 (Grass) } \\
\hline Within & GAU & 0.20 & 0.097 & 9.24 & 0.67 \\
\hline Outside & SPH & 0.08 & 0.041 & 14.77 & 0.37 \\
\hline
\end{tabular}

${ }^{\mathrm{a}} \mathrm{EXP}$ (Exponential), GAU (Gaussian), ESF (Spherical); ${ }^{\mathrm{b}} \mathrm{C}_{0}=$ nugget effect; $\mathrm{C}_{1}=$ structural variance; $\mathrm{a}=$ range

fertility. As a result of the sandy texture and low organic matter content, which act in the formation of aggregates, the soil structure is poor and consequently, the soil water retention is limited. The low soil water retention associated with high evapotranspiration and temperature, make the environment very fragile in terms of crop yield. Furthermore, the sandy texture and the poor soil structure, associated with the occurrence of long slopes and low soil cover with crop residues, result in high soil susceptibility to erosion.

In $2009 / 10$ and $2010 / 11$ growing seasons, the average soybean yields were 3,120 and $3,300 \mathrm{~kg} \mathrm{ha}^{-1}$, respectively. There was no difference in the soybean yields grown with and without the tree component. In these growing seasons, the only loss related to soybean was the absence of soybean plants within a strip of $1.5 \mathrm{~m}$ wide at each side of the eucalyptus rows. The similar soybean performance with or without the tree component can be attributed to the relatively small size of the eucalyptus plants in the first two years, resulting in low shading and competition for water, light and nutrients.

In 2011/12, the maximum soybean yield observed in the area without eucalyptus was $2.790 \mathrm{~kg} \mathrm{ha}^{-1}$, and this value was used to normalize the soybean yields in this growing season. Therefore, the normalized average soybean yield was $96.2 \%$ (ranging from 73.4 to $100.0 \%$ ) in the absence and $93.3 \%$ (ranging from 55.7 to $106.8 \%$ ) in the presence of eucalyptus. The average loss in soybean yields caused by eucalyptus was $2.9 \%$. The variability of soybean yields was higher within than outside the eucalyptus rows, $137.7 \%$ to $21.9 \%$, respectively. According to Garcez Neto et al. (2010), the tree component provides a spatially heterogeneous microclimate, leading to high spatial yield variability in understory crops. In the 3rd year after the eucalyptus planting, the soybean yields near the tree rows were significantly lower than in the area without the tree component (Figure 1), most likely due to the competition for environmental resources (light, water, and nutrients) imposed by the eucalyptus.

In 2012/13, the normalized average soybean yield in relation to the highest yield value outside the eucalyptus rows $\left(2,964 \mathrm{~kg} \mathrm{ha}^{-1}\right.$ ) was $97.6 \%$ (ranging from 63.6 to $100.0 \%$ ) without trees, and $70.6 \%$ (ranging between 39.5 and $85.1 \%$ ) in the presence of trees. The average yield loss caused by the trees in 2012/13 was higher than 2011/12, reaching aproximately $27.0 \%$ (Table 2, Figure 2). Similarly to 2011/12, the soybean yield variability was higher between the tree rows relative to the area without trees, $100.0 \%$ to $60.9 \%$, respectively. Accordingly, in a CLFS with low density of eucalyptus plants, but with narrow row spacing $(14 \mathrm{~m})$, the soybean can be grown without significant yield reduction only until the 3rd growing season after the eucalyptus planting.

The tree component led to substantial soybean yield losses in the 4st growing season (2012/13), mainly due to the higher capacity of the eucalyptus to compete for light, water and nutrients. Thus, for the soybean yield determination, the negative effect exerted by the eucalyptus competition for environmental resources overcame possible benefits on the understory microclimate, such as lower maximum temperatures, increased relative humidity and decreased evapotranspiration (BERNARDINO, GARCIA, 2009; SOUZA et al., 2010). One way to reduce the negative effect of eucalyptus on the soybean yield is using a wider tree row spacing (more than $14 \mathrm{~m}$, used in this 
Figure 1 - Maps of the normalized average soybean yield (\%) from areas within and outside the tree rows in an integrated crop-livestock-forest farming system, in 2011/12 growing season, at Santo Inácio-PR

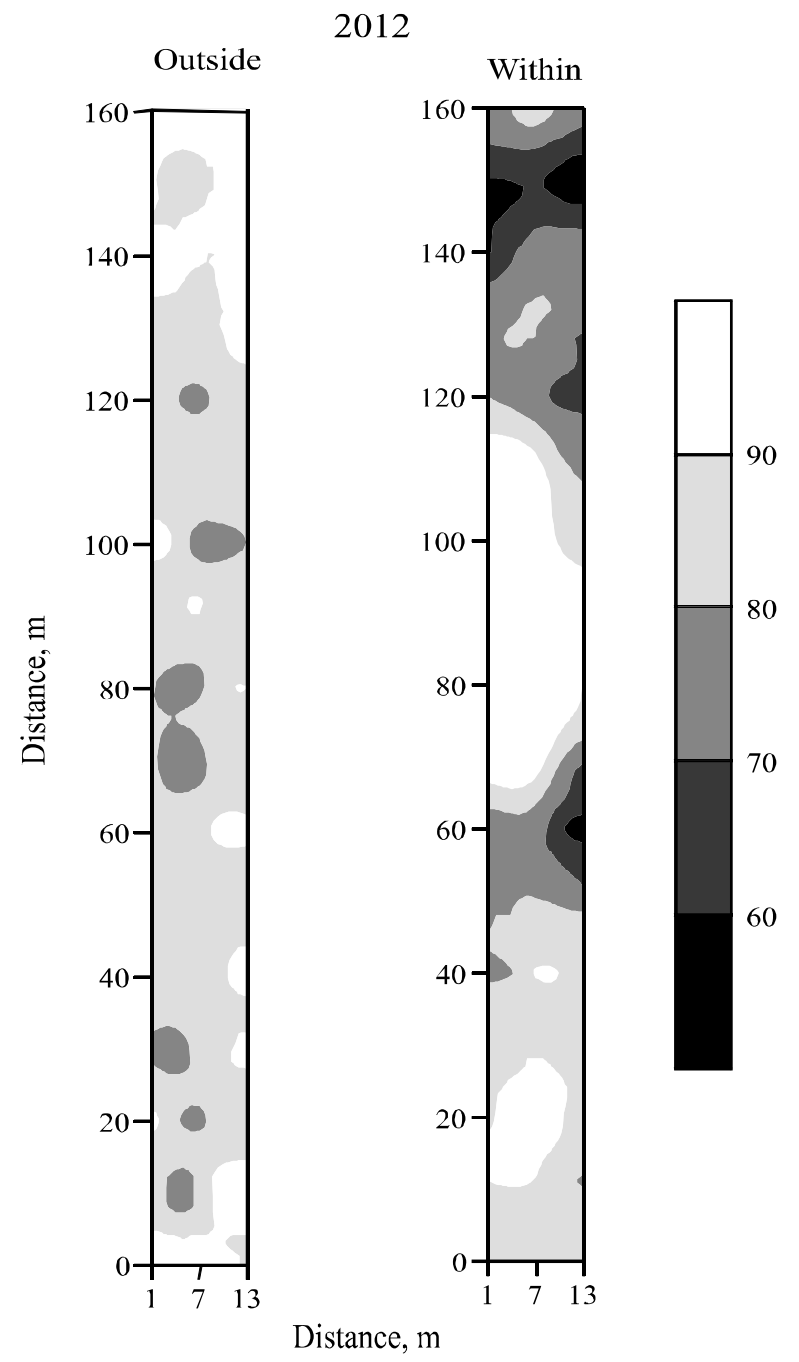

study), leading to lower light interception, water and nutrients use by the trees.

The percent differences between the normalized soybean yields within and outside the eucalyptus rows were highly dependent on the sampling position between the eucalyptus rows, as well as on the growing season (Figure 3 ). On average, the soybean yield losses were higher in the closer positions to the tree rows in both growing seasons. In 2011/12, the average soybean yields were reduced in $2.5 \%$ in the shaded positions during the afternoon (left side of Figure 3). When the soybean plants were exposed to the sun light in the afternoon (right side of Figure 3), the yield losses
Figure 2 - Maps of the normalized average soybean yield (\%) from areas within and outside the tree rows in an integrated croplivestock-forest farming system, in 2012/13 growing season, at Santo Inácio-PR

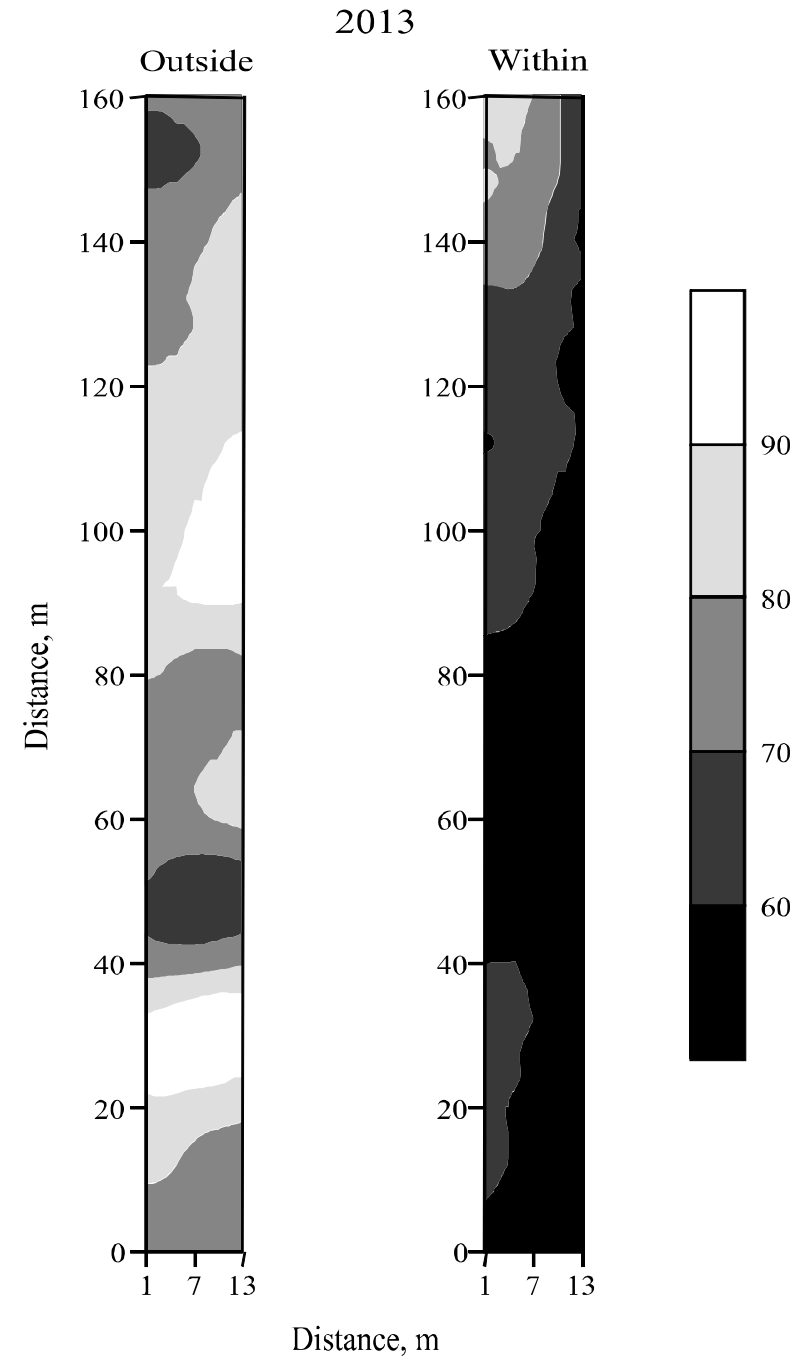

were increased to $8.9 \%$. In contrast, soybean yields were $2.9 \%$ higher in the intermediate portion (4 to 7 $\mathrm{m})$ of the tree row spacing than in the area without eucalyptus. The results obtained in 2011/12 were partially repeated in 2012/2013, with lower soybean yield losses in shaded (21.2\%, left side of Figure 3$)$ than in sun-exposed (33.6\%, right side of Figure 3 ) positions during the afternoon. However, the soybean yield losses caused by the eucalyptus were larger in 2012/13 comparatively 2011/12. Additionally, none of the positions between eucalyptus rows presented higher soybean yield when compared with the nonforested area in 2012/13 (Figure 3). 
Figure 3 - Normalized soybean yield difference between areas within and outside tree rows in an integrated croplivestock-forest farming system, in 2011/12 and 2012/13 growing seasons, at Santo Inácio-PR

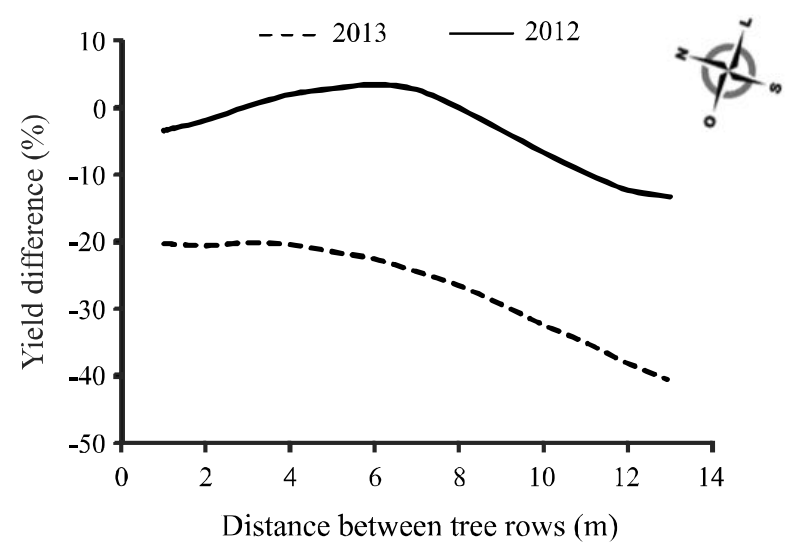

The increase in the tree height leads to a larger shaded area between the tree rows, but this effect seems to be less important than competition for water to explain the soybean yield losses caused by the eucalyptus presence in a CLFS. The hypothesis that the competition between trees and annual crops is mostly for water is supported by the higher soybean yield losses in sun-exposed than in shaded positions during the afternoon. Accordingly, plants exposed to the sun during the afternoon probably require more water, which in turn is less available due to the consumption by the trees. Moreover, the low water storage capacity related to the high soil sand content in the experimental area (Table 1) probably increased the effects of the competition for water on soybean yields.

The shoot dry mass production of $U$. ruziziensis at 33 months after the eucalyptus planting was substantially reduced by the tree component (Figure 4). This evaluation was carried out in July 2012, at a period characterized by low water availability. Similarly to the soybean, the greatest reduction in the shoot dry mater production of $U$. ruziziensis was observed near the eucalyptus rows due to increased competition for water, light and nutrients. Paciullo et al. (2011) found lower fodder production of $U$. decumbens close to the tree rows compared to the central region between tree rows, which were spaced $30 \mathrm{~m}$ apart. The same authors observed increased fodder production and crude protein content in a strip located at 7 to $10 \mathrm{~m}$ from the tree rows. Oliveira et al. (2007) also found higher Urochloa brizantha fodder production in the central region between the eucalyptus rows than near the tree rows. Considering that the response to partial shading is widely variable among grass species (PACIOULLO et al., 2008), it is necessary to evaluate the performance
Figure 4 - Maps of normalized shoot dry mass production (\%) of Urochloa ruziziensis from areas within and outside the tree rows in an integrated crop-livestock-forest farming system, at 33 months after the eucalyptus planting (July/2012), at Santo Inácio-PR

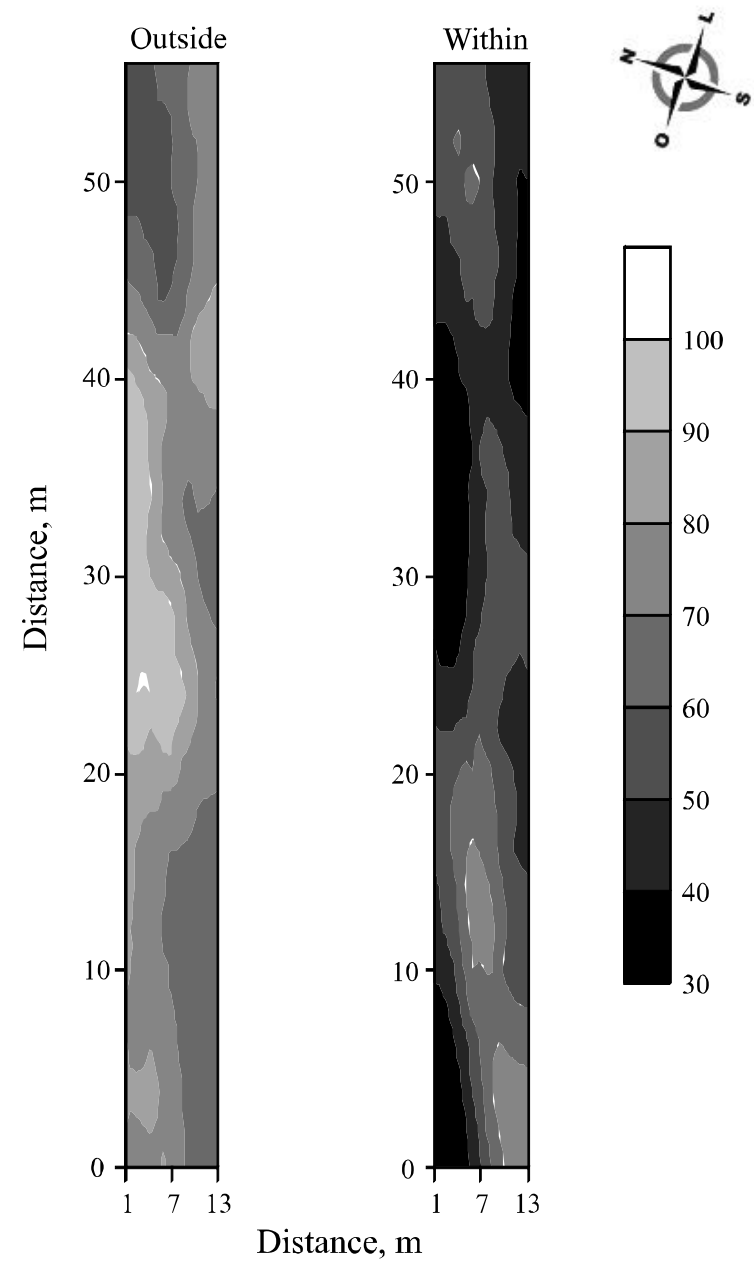

of other forage species in silvopastoral systems in the Northwestern Paraná, Brazil.

The eucalyptus density at 19 months after planting was 165 plants ha $^{-1}$, indicating a loss of only 5 plants ha${ }^{1}$, which represents approximately $3 \%$ of the total plant population at planting (Table 3 ). The mortality rate at 35 months after planting increased to about $14 \%$, which is higher than the mortality rate of $8 \%$ after 7.6 years reported by Matrangolo et al. (2010) in a single planting. This high mortality rate may be attributed mainly to the tree breaking caused by the wind action, which has been frequent in conditions of low plant density, commonly observed in CLFS. Furthermore, the growth rate of any forest species is greater in agricultural areas with high soil fertility than in the marginal areas normally used for forestry, and this faster growth can increase the tree susceptibility to the breaking by wind. From 19 to 33 
Table 3 - Eucalyptus growth variables in an integrated crop-livestock-forest farming system, at Santo Inácio, PR

\begin{tabular}{cccccc}
\hline Age (months) & $\begin{array}{c}\text { Density } \\
\left(\text { plants ha }{ }^{-1}\right)\end{array}$ & $\begin{array}{c}\text { Plant height } \\
(\mathrm{m})\end{array}$ & $\begin{array}{c}\text { Trunk diameter } \\
(\mathrm{m})\end{array}$ & $\begin{array}{c}\text { Wood volume } \\
\left(\mathrm{m}^{3} \text { plant }^{-1}\right)\end{array}$ & $\begin{array}{c}\text { Wood volume } \\
\left(\mathrm{m}^{3} \mathrm{ha}^{-1}\right)\end{array}$ \\
\hline 19 & 165 & 5.6 & 0.055 & 0.0044 & 0.73 \\
35 & 146 & 10.1 & 0.116 & 0.0350 & 5.12 \\
\hline
\end{tabular}

months after the eucalyptus planting, the eucalyptus plant height, trunk diameter and wood volume increased from 19 to 33 months after planting, demonstrating the high potential of this species for timber production in Northwestern Paraná.

\section{CONCLUSIONS}

1. The tree component did not affect soybean yield in the first two years, but in the 3rd and 4th growing seasons, the soybean yield losses caused by the eucalyptus were 2.9 and $27.0 \%$, respectively, being more intense near the trees rows;

2. The tree component reduced the shoot dry mass production of $U$. ruziziensis by $29.2 \%$ at 33 months after eucalyptus planting;

3. The eucalyptus wood production was 0.73 and $5.17 \mathrm{~m}^{3}$ ha $^{-1}$ at 19 and 35 months after planting, respectively.

\section{ACKNOWLEDGMENTS}

Manuscript approved for publication by the Editorial Board of Embrapa Soja (36/2013). A. A. Balbinot Junior receives a fellowship of technological development and innovative extension from CNPq.

\section{REFERENCES}

BALBINOT JUNIOR, A.A. et al. Winter pasture and cover crops and their effects on soil and summer grain crops. Pesquisa Agropecuária Brasileira, v. 46, n. 10, p. 13571363, 2011.

BERNARDINO, F.S.; GARCIA, R. Sistemas silvipastoris. Pesquisa Florestal Brasileira, v. 60, p. 77-87, 2009.

CARVALHO, P.C.F. et al. Managing grazing animals to achieve nutriente cycling and soil improvement in no-till integrated systems. Nutrient Cycling in Agroecosystems, v. 88, n. 2 , p. $259-273,2010$.

COSTA, M.A.T. et al. Resistência do solo à penetração e produção de raízes e de forragem em diferentes níveis de intensificação do pastejo. Revista Brasileira de Ciência do Solo, v. 36, n. 3, p. 993-1004, 2012.

FIDALSKI, J. et al. Influência das frações de areia na retenção e disponibilidade de água em solos das formações Caiuá e Paranavaí. Revista Brasileira de Ciência do Solo, Viçosa, v. 37, n. 3, p. 613-621, 2013.

FOLEY, J.A. et al. Global consequences of land use. Science, v. 309 , p. $570-574,2005$.

FRANCHINI, J. C.; SILVA, V. P. da; BALBINOT-JR, A. A.; SICHIERI, F.; PADULLA, R.; DEBIASI, H.; MARTINS, S. S. Integração lavoura-pecuária-floresta na região noroeste do Paraná. Londrina: Embrapa Soja, 2011. 14 p. (Embrapa Soja. Circular Técnica, 86).

GARCEZ NETO, A.F. et al. Aclimatação morfológica de forrageiras temperadas a padrões e níveis de sombreamento. Revista Brasileira de Zootecnia, v. 39, n. 1, p. 42-50, 2010.

LIMA, J. S. S.; et al. Variabilidade espacial de atributos físicos de um Argissolo vermelho-amarelo sob pastagem e vegetação secundária em regeneração natural. Engenharia Agrícola, v. 29, n. 2, p. 185-195, 2009.

MATRANGOLO, C.A.R. et al. Crescimento de eucalipto sob efeito de desfolhamento artificial. Pesquisa Agropecuária Brasileira, v. 45, n. 9, p. 952-957, 2010

MIGUEL, F. R. M.; VIEIRA, S. R.; GREGO, C. R. Variabilidade espacial da infiltração de água em solo sob pastagem em função da intensidade de pisoteio. Pesquisa Agropecuária Brasileira, v. 44, n. 11, p. 1513-1519, 2009.

NAIR, P.K.R. Agroforestry systems and environmental quality: introduction. Journal of Environmental Quality, v.40, n. 3, p.784-790, 2011.

NAIR, P.K.R. et al. Carbon sequestration in agroforestry systems. Advances in Agronomy, v.108, p.237-307, 2010.

OLIVEIRA, T.K. de et al. Produtividade de Brachiaria brizantha (Hochst. ex A. Rich.) Stapf cv. Marandu sob diferentes arranjos estruturais de sistema agrossilvipastoril com eucalipto. Ciência e Agrotecnologia, v. 31, n. 3, p. 748757, 2007.

PACIOULLO, D.S.C. et al. Crescimento de capim-braquiária influenciado pelo grau de sobreamento e pela estação do ano. Pesquisa Agropecuária Brasileira, v. 43, n. 7, p. 917-923, 2008.

PACIULLO, D.S.C. et al. Características produtivas e nutricionais do pasto em sistema agrossilvipastoril, conforme a 
distância das árvores. Pesquisa Agropecuária Brasileira, v. 46, n. 10, p. 1176-1183, 2011.

REGANOLD, J.P. et al. Transforming U.S. agriculture. Science, v. 332, p. 670-671.

ROZADOS-LORENZO, M.J. et al. Pasture production under different tree species and densities in an Atlantic silvopastoral system. Agroforestry System, v. 70, n. 1, p. 53-62, 2007.

SÁ, J.P.G.; CAVIGLIONE, J.H. Arenito Caiuá: capacidade de lotação das pastagens. Informe de Pesquisa, n.132, 1999.
SILVA, J. R. M. et al. Evaluation of spatial and temporal variability of pasture based on topography and the quality of the rainy season. Precision Agriculture, v. 9, p. 209-229, 2008.

SOUZA, W. de et al. Microclimate in silvipastoral systems with eucalyptus in rank with different heights. Revista Brasileira de Zootecnia, v. 39, n. 3, p. 685-694, 2010.

VIEIRA, S. et al. Handbook for geoestatistical analysis of variability in soil and climate data. Tópicos em Ciência do Solo, v.2, p.1-45, 2002. 